\title{
Atmospheric and oceanic freshwater transport during weak Atlantic overturning circulation
}

\author{
By GERRIT LOHMANN*, Geoscience Department, Bremen University, P.O. 330 440, 28334 Bremen, \\ Germany
}

(Manuscript received 11 October 2001; in final form 9 April 2003)

\begin{abstract}
Oceanic and atmospheric freshwater transports are analyzed in a numerical experiment where induced freshwater in the North Atlantic slowed the thermohaline circulation (THC). During times of weak Atlantic overturning circulation, it is found that the Intertropical Convergence Zone moves southward and trade winds at tropical latitudes increase, resulting in enhanced water vapor export out of the Atlantic catchment area. The experiment reveals furthermore that the oceanic freshwater transport amounts to a stabilizing effect of similar magnitude to the atmospheric effect. It is argued that the modeled response can be used as a fingerprint for the detection of THC changes documented in the paleoclimatic record or related recent climate change.
\end{abstract}

\section{Introduction}

"Everything is based on water" stated the Greek philosopher Thales of Milet (ca. 580 years B.C.) according to history (Capelle, 1953). Thales' statement of water had originated from his observation of the Aegean Sea that water is evaporated from the heated sea, leading to clouds which are dissolved again into rain. What he described is basically a consequence of the general principle of the conservation of water substance in its three phases on the Earth. This issue is particularly relevant for paleoclimatic and recent climate changes, because water must be regarded as one of the most important links among the subsystems of the climate system since it connects them all.

The atmospheric water cycle connects different water reservoirs and has a high mobility. The residence time of water in the different reservoirs varies from nine days for atmospheric water to thousands of years for the polar ice and the oceans (Peixoto and Oort, 1992; Baumgartner and Reichel, 1975). Of particular interest is the ocean because the large-scale cir-

\footnotetext{
${ }^{*}$ Corresponding author. e-mail: gerrit.lohmann@dkrz.de
}

culation is strongly affected by the atmospheric surface freshwater forcing. There is some evidence from paleoclimatic records (e.g. Dansgaard et al., 1993; Clark et al., 2001) and modeling studies (Bryan, 1986; Rahmstorf, 1995; Lohmann and Gerdes, 1998; Renssen et al., 2001) that changes in the freshwater forcing can trigger transitions between multiple equilibria of ocean circulation.

The present large-scale thermohaline circulation (THC) in the Atlantic ocean carries water with a mass transport of about $17 \times 10^{9} \mathrm{~kg} \mathrm{~s}^{-1}$ (Roemmich and Wunsch, 1985). In the upper ocean, saline water is advected into the northern North Atlantic and is cooled, making the water dense enough for deep-water formation in the Norwegian and Labrador Seas. This water re-circulates back as North Atlantic Deep Water (NADW) and joins the Antarctic Circumpolar Current (ACC) in the Southern Ocean. The global conveyor belt circulation (Broecker, 1991) is responsible for an ocean heat transport in the North Atlantic of about $10^{15} \mathrm{~W}$, which is comparable to the heat transport of the atmosphere. A changed large-scale ocean circulation with a reduced poleward heat transport has a large impact on the climate conditions in the North Atlantic and surrounding areas (Manabe and Stouffer, 1988; Renssen et al., 2001). 
Variations in the hydrological cycle have been documented in the past (Peterson et al., 2000; Haug et al., 2001). Peterson et al. (2000) proposed that higher net export of moisture to the Pacific affects NADW formation by enhancing the Atlantic salinity. These studies highlight the interaction between low and high latitudes for climate changes, especially the potential importance of tropical water vapor transport over the American continent for climate changes. Motivated by these studies, we examine the thermal response and water vapor routes during times when the ocean circulation is considerably weakened. For that purpose, a meltwater scenario with the coupled atmosphere-ocean model ECHAM3/LSG (Voss et al., 1998; Schiller et al., 1997) is used. The relationships between the temperature response, interbasin ocean transport, Atlantic salinity and overturning circulation are considered in the coupled atmosphere-ocean model. The model results are then used for a new interpretation of paleoclimatic records.

This paper is organized as follows. The model is introduced in section 2.1. Following this, the ocean circulation (2.2), atmospheric water vapor transport (2.3) and mass balance in the Atlantic Ocean (2.4) are elaborated. In section 3 the response of the coupled atmosphere-ocean system to a freshwater perturbation is described and the changes in atmospheric and oceanic freshwater transports are discussed. Finally, paleoclimatic interpretations and conclusions (section 4) are given.

\section{Methodology and control climate}

\subsection{Model}

The coupled model consists of the atmospheric circulation model ECHAM3 (Roeckner et al., 1992), the ocean primitive equation model LSG (Maier-Reimer et al., 1993) and the runoff model of Sausen et al. (1994). The ocean model has a free surface and includes a thermodynamic sea ice model. The coupled model with acronym ECHAM3/LSG has a horizontal resolution of about $5.6^{\circ}$. To reduce the climate drift of the model, a flux correction method is applied (Sausen et al., 1988). This model has been used in a number of climate change experiments and estimation of natural climate variability (references in Voss et al., 1998).

Control integration and scenario runs have been calculated with the fully coupled model and with a model version using the periodically synchronous integration technique (Sausen and Voss, 1996; Voss and
Sausen, 1996). Basically, the coupled atmosphereocean phases alternate with ocean-only phases where the surface fluxes are taken from the fully coupled phases. This integration technique saves computational costs and has been developed for long-term climate variability integrations. It has been shown that the overall response for the fully coupled and periodically synchronous coupled model versions are very similar (Voss and Sausen, 1996; Voss et al., 1998). Because longer time series are available for the latter model version, we discuss the results from the periodically synchronous coupled atmosphere-ocean model.

\subsection{Ocean circulation}

A useful diagnostic quantity is the meridional overturning stream function offering an integral representation of the basin-wide THC. The overturning stream function for the Atlantic Ocean and zonal mean salinity are shown in Fig. 1. The maximum overturning is about $25 \mathrm{~Sv}$ and the maximum flow at $30^{\circ} \mathrm{S}$ is about $17 \mathrm{~Sv}$ (Fig. 1). The relatively fresh Antarctic Intermediate Water (AAIW) and Antarctic Bottom Water (AABW), and the salty subtropical water and NADW are seen in the zonally averaged salinity of the Atlantic Ocean (Fig. 1). Compared with observations, the NADW is somewhat too salty. South of $40^{\circ} \mathrm{S}$ a subtropical front is detected in the figure. In the model, the return flow of the global circulation is mainly through the Drake Passage and upwelling occurs mainly in the Pacific and Indian Oceans (Drijfhout et al., 1996). Therefore, the cold water route (Gordon, 1986; Broecker, 1991; Rintoul, 1991) is preferred in the control run of the model.

Figure 2 shows the different water mass characteristics at $30^{\circ} \mathrm{S}$. Besides the inflow of AAIW at about $1000 \mathrm{~m}$, the inflow of AABW below $3500 \mathrm{~m}$ can be seen. Between these relatively fresh water masses of AABW and AAIW, there is an outflow of NADW with western intensification (west of $30^{\circ} \mathrm{W}$ ). This NADW outflow enters the ACC south of $60^{\circ} \mathrm{S}$ at a depth of 700-3500 $\mathrm{m}$ in the model. Furthermore, the western boundary current above $500 \mathrm{~m}$ (Brazil Current), part of the subtropical gyre, and the northward flowing Benguela Current on the eastern side are indicated in Fig. 2.

\subsection{Water vapor transport}

To investigate the hydrological forcing of the THC, the atmospheric water vapor paths are analyzed. In 


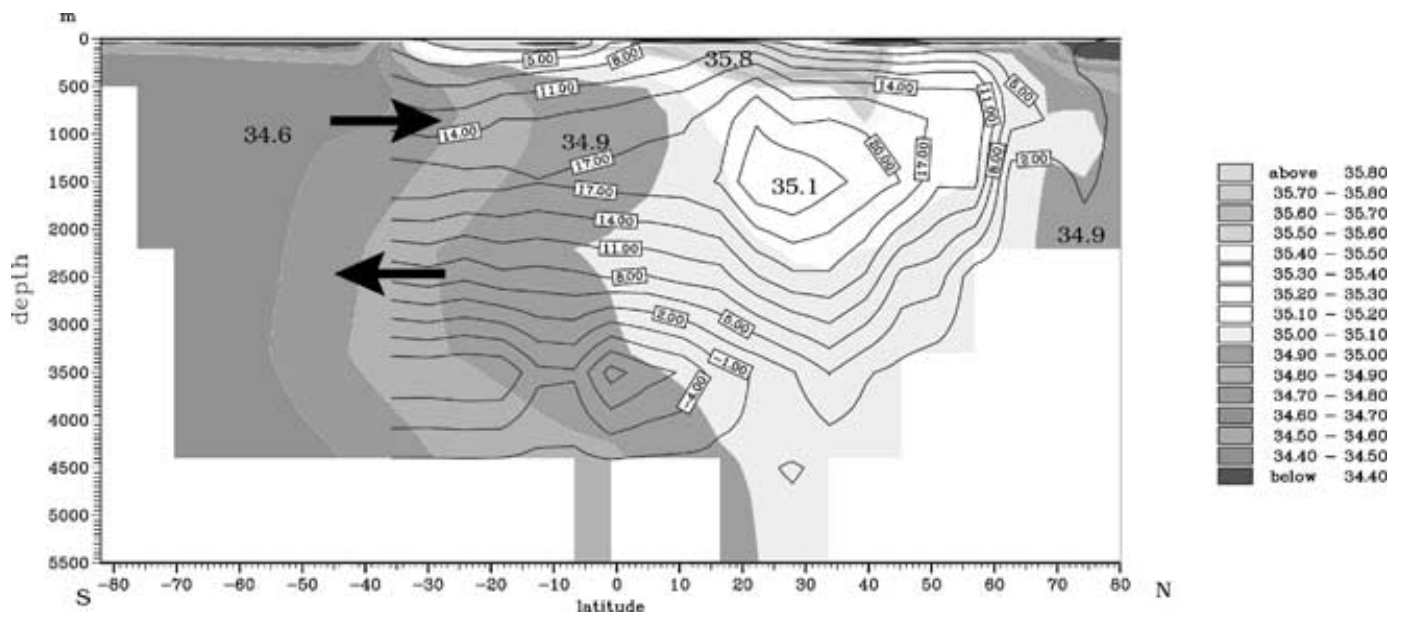

Fig. 1. Meridional overturning stream function and zonal mean salinity in the Atlantic ocean for the control experiment. The boundaries for the Atlantic Ocean section in this figure have been defined by Drake Passage and a section south of Africa. Units are psu and Sv, respectively.

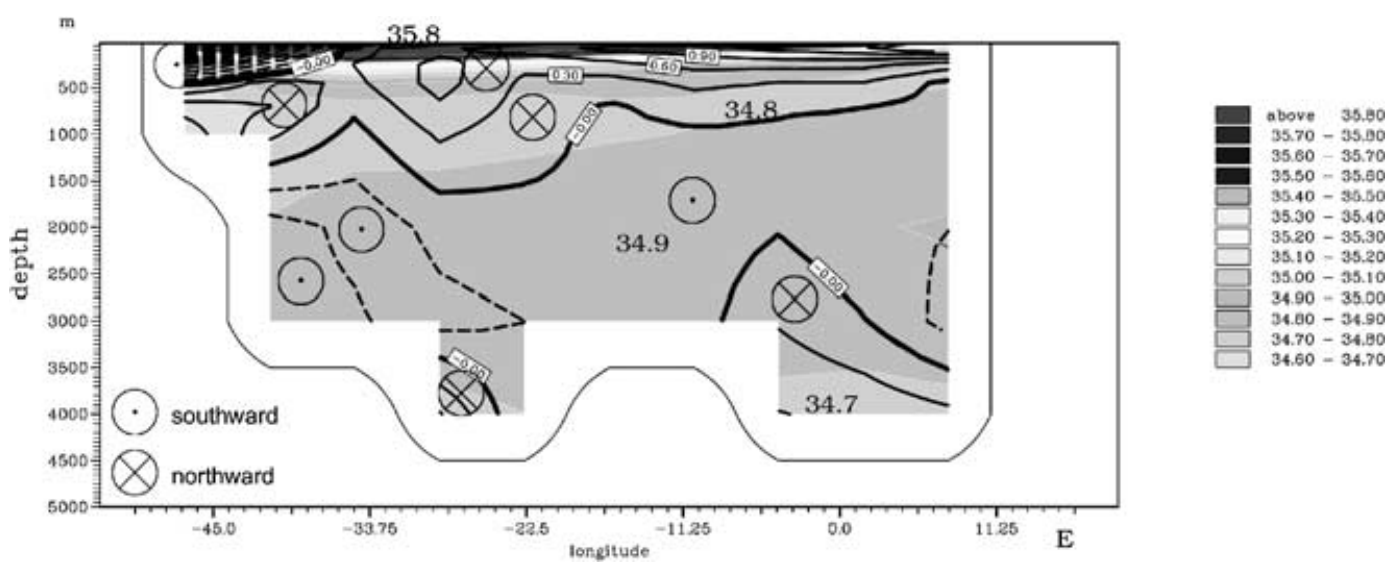

Fig. 2. Salinity and velocity at $30^{\circ} \mathrm{S}$ for the control experiment. Negative velocity values indicate a southward transport, positive a northward. The northward transport by AABW and AAIW, with relatively low salinity, and the southward transport of the Brazil Current and NADW are seen. Units are psu and $\mathrm{cm} \mathrm{s}^{-1}$, respectively.

our analysis of the coupled atmosphere-ocean model ECHAM3/LSG, the horizontal water vapor transport

$\boldsymbol{Q}:=\int_{0}^{p_{0}} \frac{\mathrm{d} p}{g} \boldsymbol{v} q$,

is examined. $p_{0}$ denotes surface pressure, $g$ gravitational acceleration, $\boldsymbol{v}$ the horizontal velocity vector and $q$ the mass mixing ratio of water vapor. The divergence of water vapor flux $\boldsymbol{Q}$ is balanced (Starr and Peixoto, 1958; Peixoto and Oort, 1992; Wijffels et al., 1992) in equilibrium with the surface fresh water flux $E-P$ :

$\nabla \cdot Q=E-P$, where $\nabla$ denotes the two dimensional divergence operator, $E$ evapo(transpi)ration and $P$ precipitation. The horizontal transport of water in the liquid and solid phases is negligible on the large scale and is therefore neglected here.

The global water vapor transport $\boldsymbol{Q}$ is computed from the control integration, shown in Fig. 3. For our analysis of the hydrological cycle, we take years 201250 in the respective experiments. In the periodically synchronous coupled model runs, this time span provides ten independent years of atmospheric data. The figure shows the direction of water vapor transport and contains information about the sources and sinks 


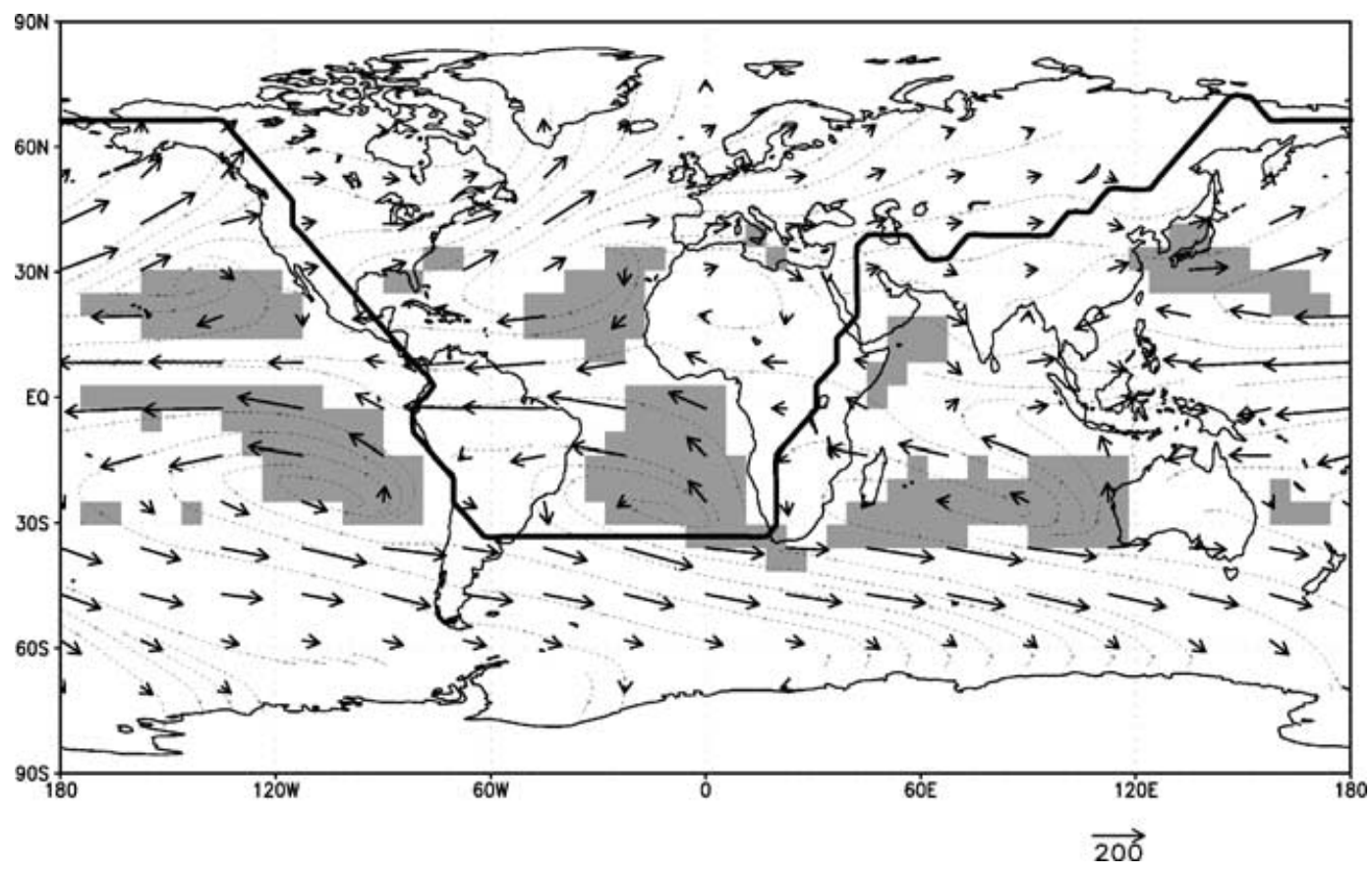

Fig. 3. Vertically integrated water vapor transport for the control experiment (in $\mathrm{kg} \mathrm{m}^{-1} \mathrm{~s}^{-1}$ ). Values of water vapor transport below $20 \mathrm{~kg} \mathrm{~m}^{-1} \mathrm{~s}^{-1}$ are suppressed. The thick black line shows the Atlantic catchment area. The shaded area indicates sources of water vapor transport with net evaporation $E-P>0.4 \mathrm{~m} \mathrm{yr}^{-1}$.

of atmospheric water vapor from the ocean and land surfaces. When $\boldsymbol{Q}$ changes along a hypothetical water vapor path, the transport decreases (increases), resulting in net precipitation (evaporation).

The water vapor transport reflects the characteristics of the general circulation of the lower troposphere. In the tropics between $20^{\circ} \mathrm{S}$ and $20^{\circ} \mathrm{N}$, strong easterlies are observed, especially over the Atlantic and Pacific Oceans. Strong westerlies occur around $45^{\circ} \mathrm{S}$ over the Southern Ocean. Furthermore, the subtropical highs over the North and South Atlantic and Pacific oceans provide a moisture transport from the subtropics to higher latitudes.

The river flow (Sausen et al., 1994) and approximated catchment areas of the ECHAM3/LSG model define the drainage divides of the Atlantic area, including the Arctic and Mediterranean Oceans, indicated in Fig. 3 by the black line. The interoceanic water vapor transport can be divided into four parts: the drainage divides over Africa and America, where the transport is in east-west direction, and the drainage divide over Asia, where the transport is mainly northsouth. The Atlantic catchment is completed at $30^{\circ} \mathrm{S}$ in the Southern Ocean. We see that the Atlantic catchment area loses water vapor over South/Central America and the Southern Ocean, whereas water vapor is transported into the Atlantic basin over Africa, North America and Asia. The general structure of the modeled global hydrological cycle in the atmospheric model ECHAM3 is in agreement with observations (Peixoto and Oort, 1992; Zaucker and Broecker, 1992; Lohmann and Lorenz, 2000) and is consistent with the dynamics of the general circulation of the atmosphere.

\subsection{Mass balance in the Atlantic Ocean}

It is useful to consider the net mass transport in the Atlantic Ocean basin, which is a balance between the Bering Strait throughflow, South Atlantic outflow at $30^{\circ} \mathrm{S}$ and the water vapor transport. The northward transport at $30^{\circ} \mathrm{S}$ is calculated to be about $0.30 \mathrm{~Sv}$ in the control run when subtracting the Bering Strait throughflow from the mass transport at $30^{\circ} \mathrm{S}$. The required net evaporation for the ocean model in order to obtain the salinities and circulation in the Atlantic ocean is 
therefore $0.30 \mathrm{~Sv}$. The analysis of the atmospheric model component indicates that the net Atlantic freshwater export is only $0.16 \mathrm{~Sv}$. This imbalance between the model components is one reason for the need of flux corrections. The flux correction procedure compensates for the basin-wide misfit between net oceanic mass and water vapor transport. The additional evaporation makes the Atlantic surface water more saline.

The underestimated water vapor export from the Atlantic seems to be a quite general model deficit of coarse-resolution atmospheric circulation models. According to Zaucker et al. (1994), the $5^{\circ}$-resolution GISS circulation model has an export of $0.13 \mathrm{~Sv}$, whereas climatology gives $0.32 \mathrm{~Sv}$, which is close to the net evaporation required for the ocean model. It is likely that the underestimated atmospheric water vapor export is due to the relatively coarse representation of orographic features in the atmospheric model. Indeed, we find too much westward transport north of $30^{\circ} \mathrm{N}$ over America compared with observations (Zaucker et al., 1994). Furthermore, a modeled summer monsoon circulation towards the Caribbean Sea is in conflict with observations. This systematic error has been detected in all resolutions of the ECHAM3 (and ECHAM4) model (not shown) and is the subject of further investigations.

\section{Meltwater experiment}

In the melt-water experiment, a large freshwater anomaly in the northern North Atlantic has been introduced. The model was integrated over 250 years with a linearly increasing amount ranging from zero up to $0.625 \mathrm{~Sv}$ in year 250. After this time, the freshwater forcing is linearly decreased to zero until year 500 . The meltwater was released in equal parts to two grid points on the Canadian coast of the Labrador Sea. The experimental setup of this scenario are described in detail by Schiller et al. (1997). Schiller et al. (1997) identified several feedbacks affecting the thermohaline circulation in this experiment, such as high-latitude cooling, an increased atmospheric cyclonic circulation over the Norwegian Sea and Ekman pumping. Here, we concentrate on the freshwater transport in the atmosphere and ocean in the meltwater experiment.

The meltwater input to the Labrador Sea forces a transient shutdown of the THC, reducing the northward heat transport in the Atlantic Ocean. The circulation recovers completely after about 600 years when the meltwater input was switched off (Schiller et al., 1997). For all types of analyses, the model output of years 201-250, are taken as for the control integration. During this time interval, NADW formation has dropped totally.

\subsection{Oceanic and thermal response}

The ceased NADW formation causes the northward heat transport to be strongly reduced, and the surface air temperature drops drastically in the northern North Atlantic realm (Fig. 4). The temperature drop is strongest over regions where the ocean is covered by sea ice after the perturbation, and downstream the subtropical gyre at the eastern side of the North Atlantic. The reduced cross-equatorial oceanic flow leads to a decrease in Northern Hemisphere temperature and an increase in Southern Hemisphere surface salinity and temperature (Fig. 5). The response in surface air temperature is statistically significant at a $90 \%$ level for regions where the values exceed $\pm 1.5 \mathrm{~K}$. The corresponding values for Southern Hemisphere sea surface salinity and temperature anomalies are approximately $\pm 0.2 \mathrm{psu}$ and $\pm 0.4 \mathrm{~K}$, respectively.

The response both in temperature and salinity show a spatial characteristic pattern at the eastern side of the South Atlantic (Fig. 5) which is due to a weakened transport from the region off Angola along the conveyor-belt circulation. In this region, positive sea surface temperature anomalies exceed $1.5 \mathrm{~K}$, and maximal temperature anomalies reach $6 \mathrm{~K}$ at $150 \mathrm{~m}$ depth. These changes in hydrography cause the upwelling to be suppressed, as indicated by nearly horizontal isohalines in Fig. 6. Characteristic changes in the circulation pattern are detected (Fig. 6) when comparing salinity and velocity fields at $30^{\circ} \mathrm{S}$ with the corresponding figure for the control integration (Fig. 2). There is an increased outflow of low salinity water by the strengthened Brazil Current.

\subsection{Atmospheric freshwater response}

Along with the cooled Northern Hemisphere (Fig. 4), the Hadley Cells move southward. The southward migration of the thermal equator causes net precipitation to be increased south of the equator and lowered north of the equator (Fig. 7). The response in the anomalous freshwater flux is statistical significant at a $90 \%$ level for regions where the values exceed $\pm 0.3 \mathrm{~m} \mathrm{yr}^{-1}$. 


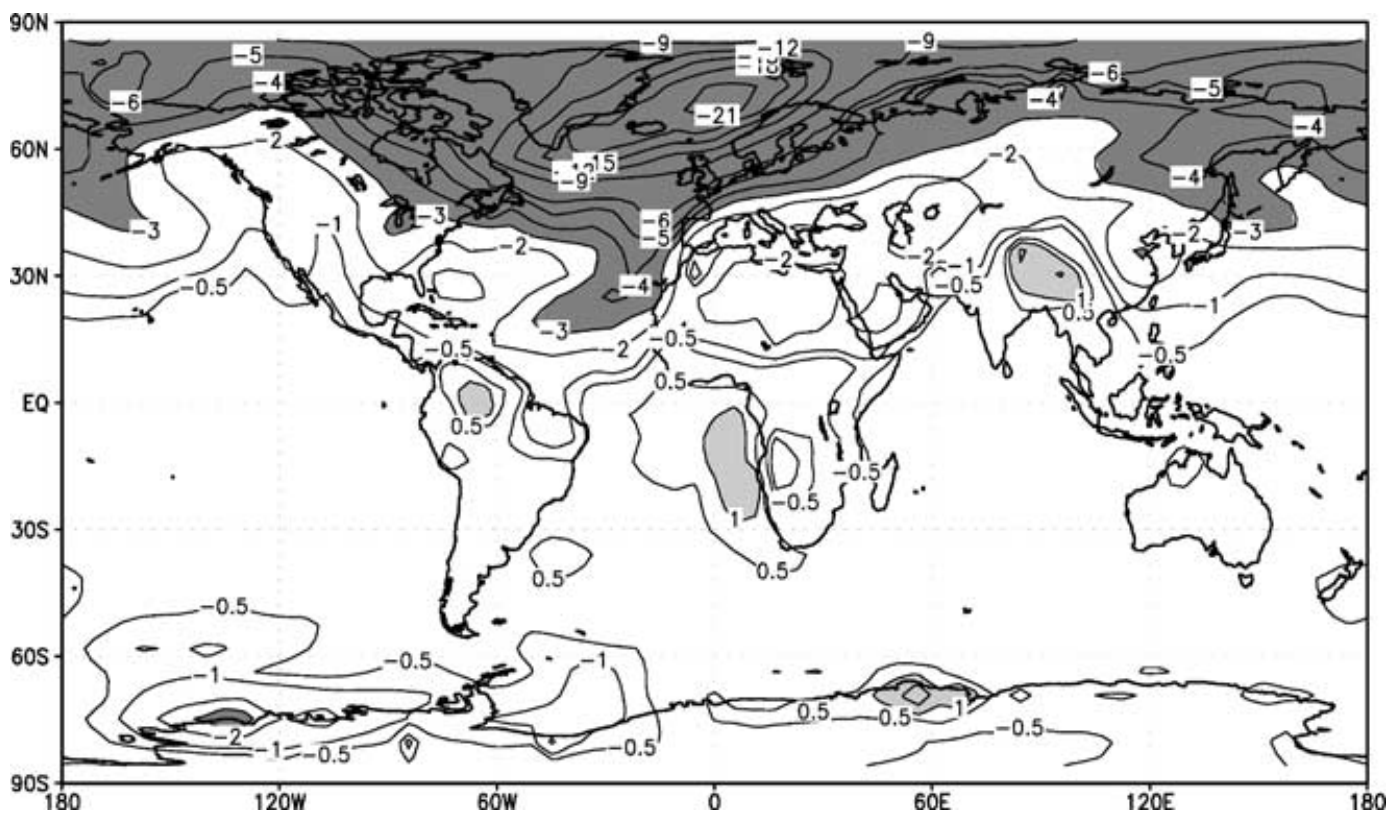

Fig. 4. Anomalous surface air temperature ( $2 \mathrm{~m}$ ) for the meltwater minus control experiment (in K).

The analysis of the water vapor transport $\boldsymbol{Q}$ at the drainage divides reveals an increased export over America $(0.10 \mathrm{~Sv})$ and decreased import over Africa $(0.06 \mathrm{~Sv})$ relative to the control experiment. The anomalous water export over Africa is connected to an anomalous low over South-East Africa, reducing the water vapor input. The increased Aleutian low and increased high in the western Pacific do not significantly affect the water vapor transport across America. Taking the whole Atlantic catchment area into account, we calculate an increase in net Atlantic evaporation of $0.15 \mathrm{~Sv}$.

The strongest change in the hydrological cycle is due to enhanced subtropical high transports from the North Atlantic to its southwestern direction water across Central America. The anomalous cold subtropical North Atlantic (Fig. 4) produces an atmospheric high-pressure system (Fig. 8). Caused by this atmospheric circulation (Fig. 8), the atmospheric water vapor export over Central America is strongly enhanced. This effect is stronger for the June-August season than for the other seasons. This moisture transport accounts for an increase of net Atlantic evaporation and therefore for a stabilizing effect for the THC. A similar effect has been proposed for tropical water vapor transport during glacials (Lohmann and Lorenz, 2000), which may be responsible for an additional sea surface salinity contrast between the Atlantic and Pacific/Indian Oceans (Broecker, 1992), and for El Niño conditions (Schmittner et al., 2000; Soden, 2000; Latif et al., 2000). Therefore, the hydrological cycle provides a stabilizing feedback for the thermohaline circulation, possibly weakening the inherently unstable climate behavior due to weak thermohaline circulation as reported by Tzipermann (1997).

\subsection{Oceanic freshwater transport}

In order to estimate the relative importance of the hydrological cycle relative to changes in the oceanic freshwater transport, the overturning component of the northward freshwater transport in the Atlantic Ocean is calculated for different times in the meltwater and control experiment. For a quantitative analysis, this transport is defined as

$F_{\text {ot }}=\int_{-h}^{0}\left(\frac{S_{\text {ref }}-\bar{S}}{S_{\text {ref }}}\right) \bar{v} \mathrm{~d} z$,

where $h$ is the ocean depth, $S_{\text {ref }}$ is a reference salinity (mean salinity of the Atlantic Ocean), and $\bar{S}$ and $\bar{v}$ denote zonally averaged salinity and integrated northward velocity, respectively. This quantity is also used in the context of THC stability with respect to 

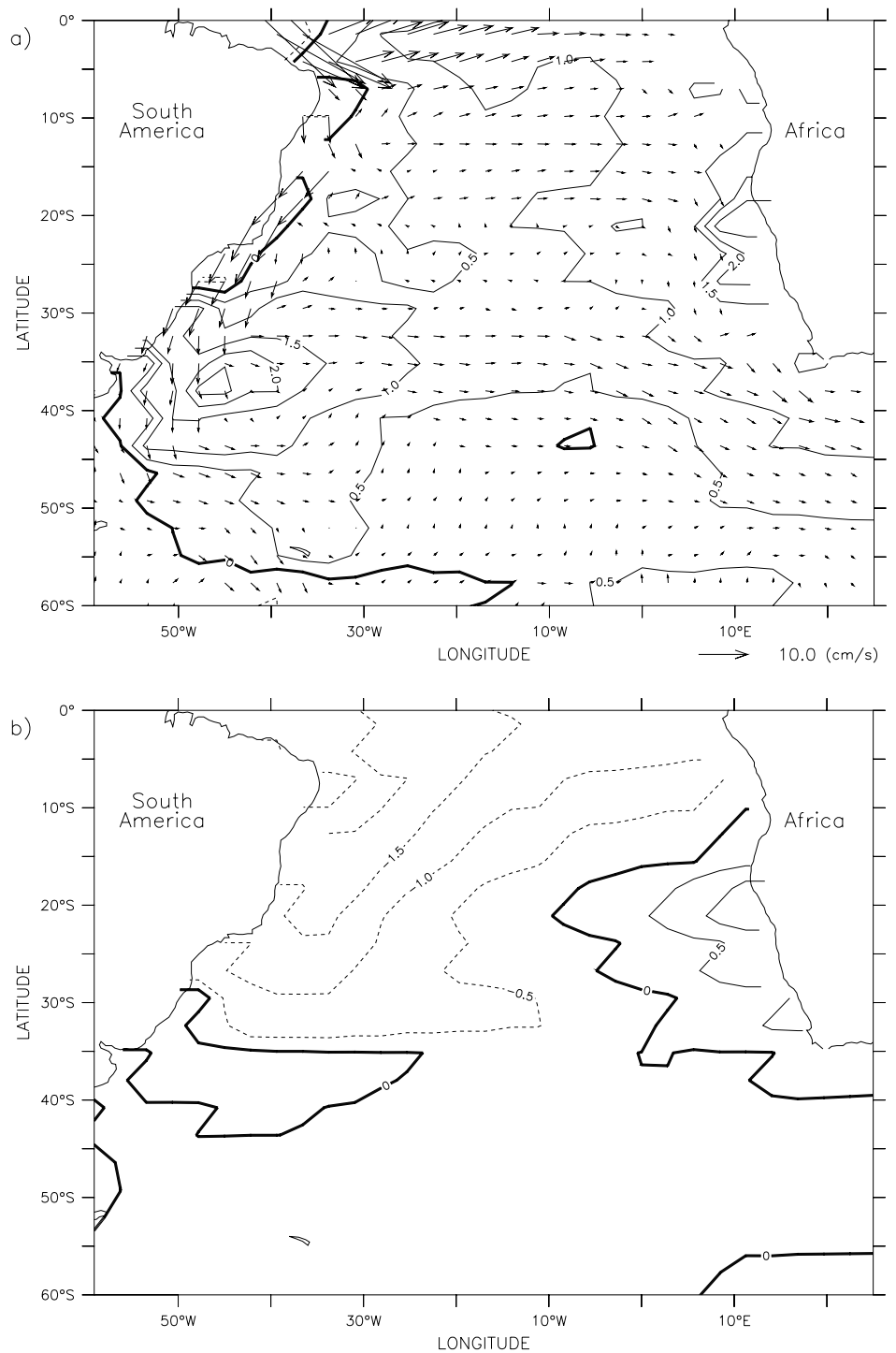

Fig. 5. Anomalous hydrography in the South Atlantic Ocean: (a) sea surface temperature and horizontal velocity, (b) salinity averaged over the upper $100 \mathrm{~m}$. Units are $\mathrm{K}, \mathrm{cm} \mathrm{s}^{-1}$ and psu, respectively.

vertical mixing (Prange et al., 2003). The above definition of $F_{\text {ot }}$ is a generalization of the effective freshwater transport as defined in Rahmstorf (1996). Equation (3) expresses the effect of salinity advection with respect to a reference salinity.

The overturning transport of freshwater is displayed in Fig. 9 for the control integration, and for the meltwater experiment 201-250 years and 801-850 years after the perturbation has been induced. In the North Atlantic Ocean, the overturning transport of freshwater is southward, i.e. a weakened conveyor belt will decrease North Atlantic salinity and increase the Southern Atlantic salinity, a mechanism similar to the seesaw principle for temperature (Crowley, 1992; Stocker, 1998). Interestingly, a southward transport is detected for the North Atlantic Ocean during the meltwater event. In contrast, the tropical South Atlantic Ocean provides for a small positive freshwater transport. The circulation in the control simulation and at years 801-850 are very similar. The difference in the overturning 


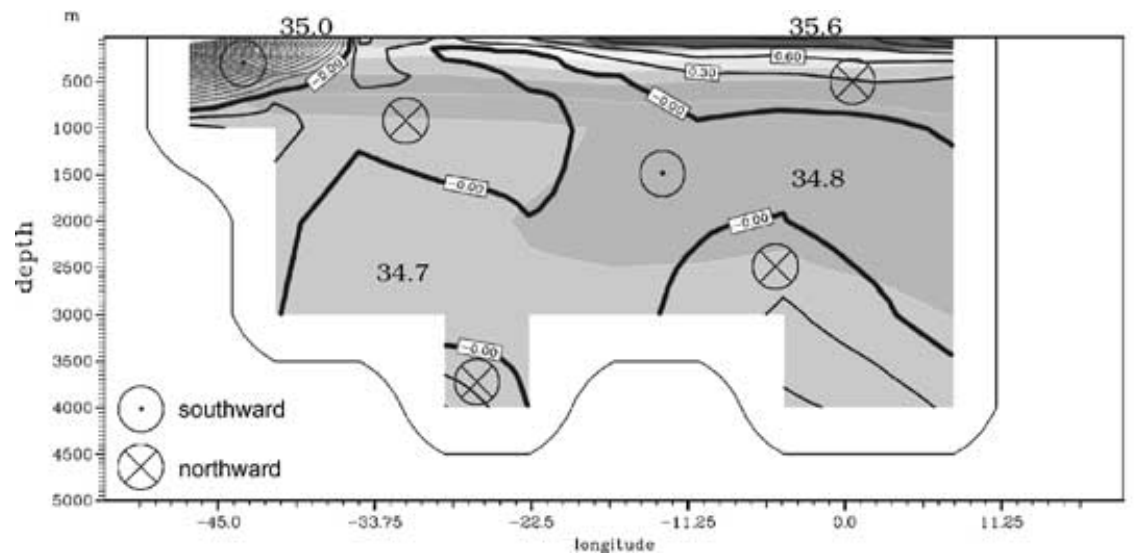

Fig. 6. Salinity and velocity at $30^{\circ} \mathrm{S}$ for the meltwater experiment. Negative velocity values indicate a southward transport, positive a northward. Units are psu and $\mathrm{cm} \mathrm{s}^{-1}$, respectively.

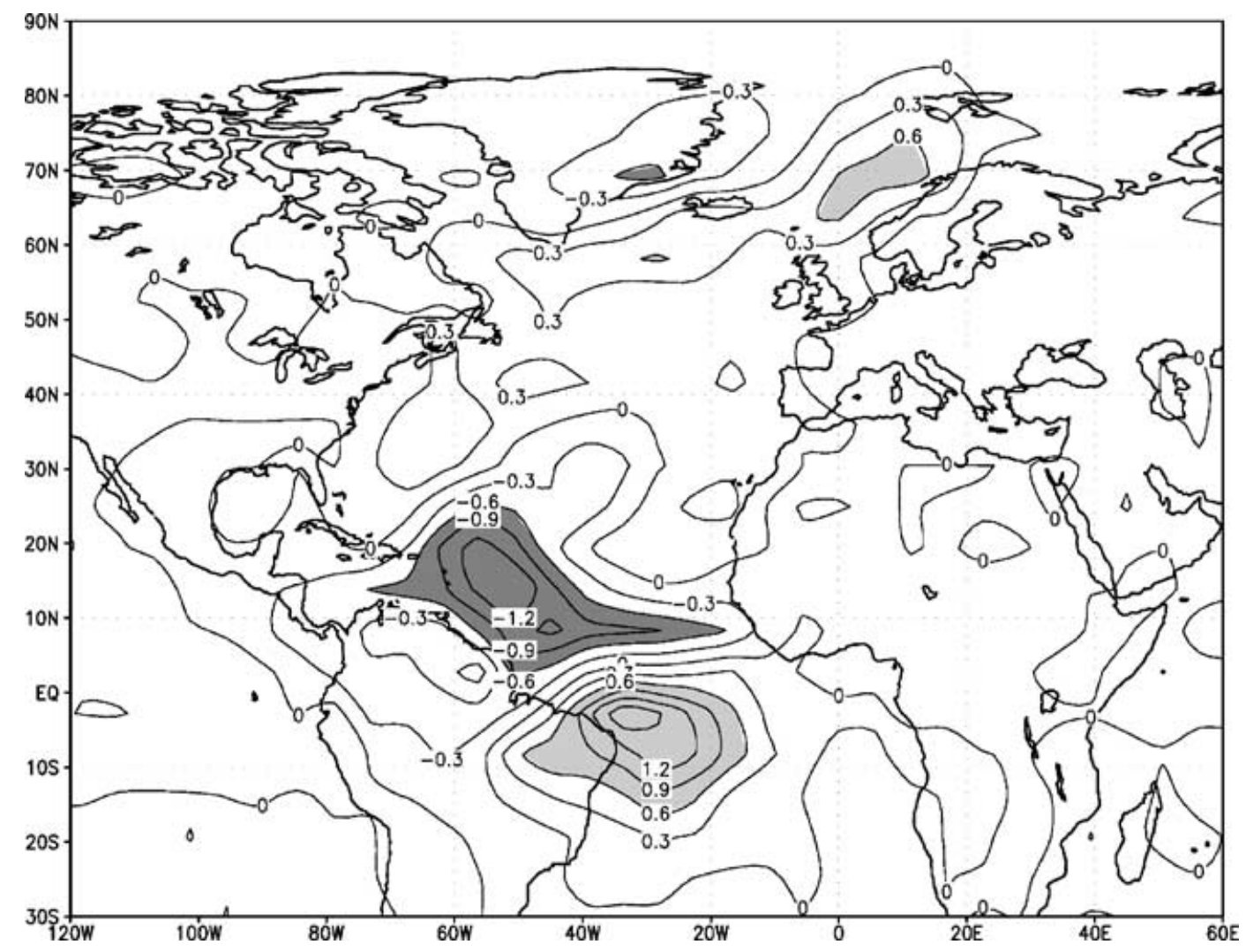

Fig. 7. Anomalous annual mean freshwater flux $P-E\left(\right.$ in $\mathrm{m} \mathrm{yr}^{-1}$ ). Values greater than $0.6 \mathrm{~m} \mathrm{yr}^{-1}$ and less than $-0.6 \mathrm{~m} \mathrm{yr}^{-1}$ are shaded light and dark gray, respectively.

Tellus 55A (2003), 5 


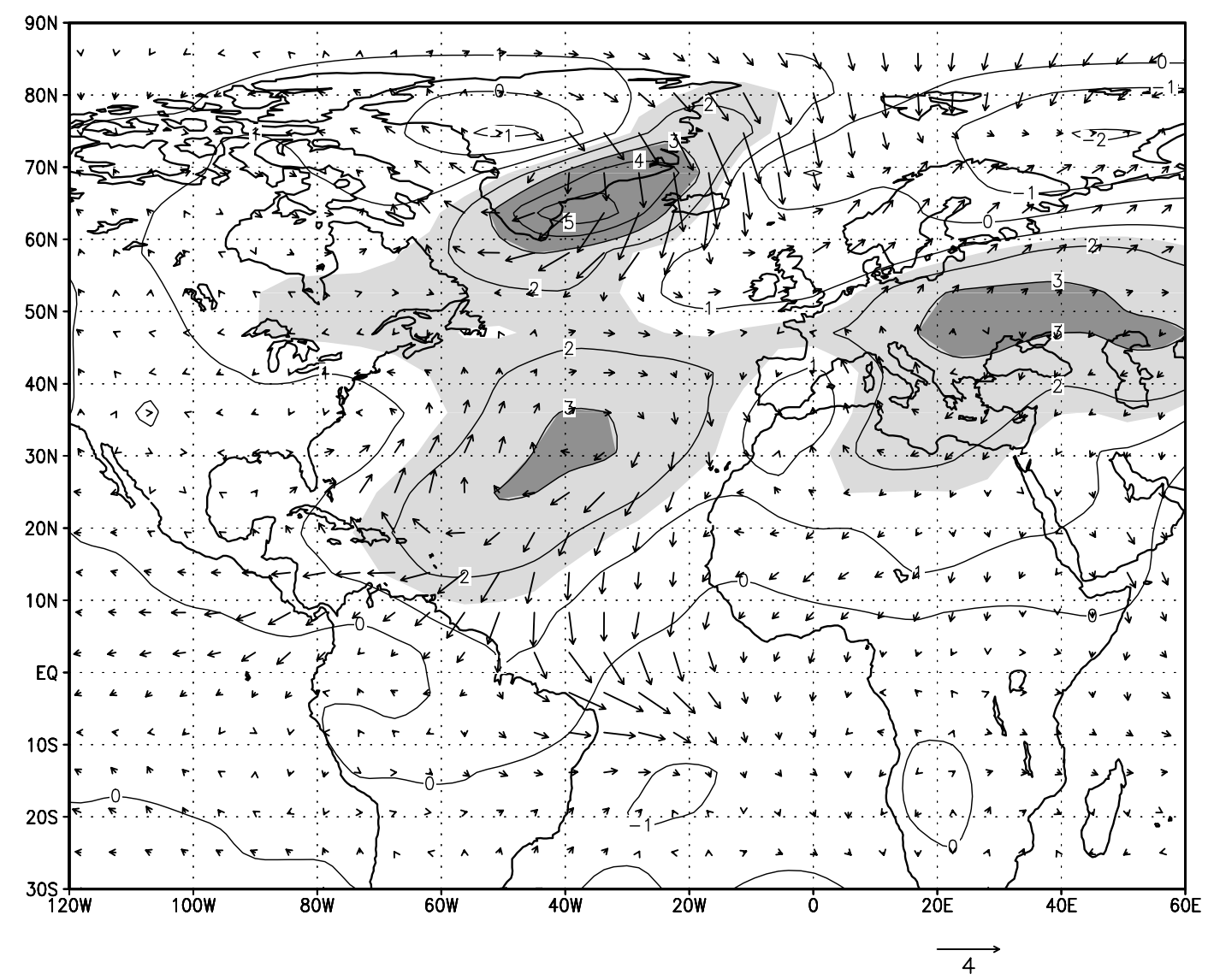

Fig. 8. Anomalous sea level pressure and surface $850 \mathrm{hPa}$ wind (annual mean). Units are $\mathrm{hPa}$ and $\mathrm{m} \mathrm{s}^{-1}$. Sea level pressure anomalies above 1.5 and $3 \mathrm{hPa}$ are light- and dark-shaded, respectively. The anomalous wind is $4 \mathrm{~m} \mathrm{~s}^{-1}$ maximal.

transport of freshwater at about $40^{\circ} \mathrm{N}$ is due to the lowered surface salinity originating from the freshening in this region. In the transient phase, the overturning transport of freshwater in the North Atlantic is directed southward, which is caused by southward transport of fresh surface water and northward transport of relatively saline water related to the THC offmode. From the amplitudes, it can be concluded that both the increase of net Atlantic evaporation and southward transport of fresh surface water by the ocean are of comparable size contributing to the resumption of the THC.

\subsection{Discussion}

There are different concepts of the THC freshwater forcing and sensitivity. Single hemispheric models such as the Stommel (1961) box model propose that high-latitude freshening brakes the flow, whereas low-latitude freshening increases the flow. Sensitivity experiments (Zaucker et al., 1994; Rahmstorf, 1996) indicate that the latitudinal structure of the freshwater fluxes in low and mid latitudes has little influence on the modeled THC indicating that single hemispheric models provide not for a proper description of the sensitivity of the system.

However, there is apparently a controversy about the branch and the haline response of the present day THC. Some authors (Broecker et al., 1990; Broecker, 1991; Zaucker and Broecker, 1992) propose that the overall effect of the freshwater forcing felt by the Atlantic conveyor belt is a net freshwater loss (i.e. salinity enrichment due to the net Atlantic water vapor export, haline branch). Rahmstorf (1996) propose on the other hand that a salinity enrichment along the 


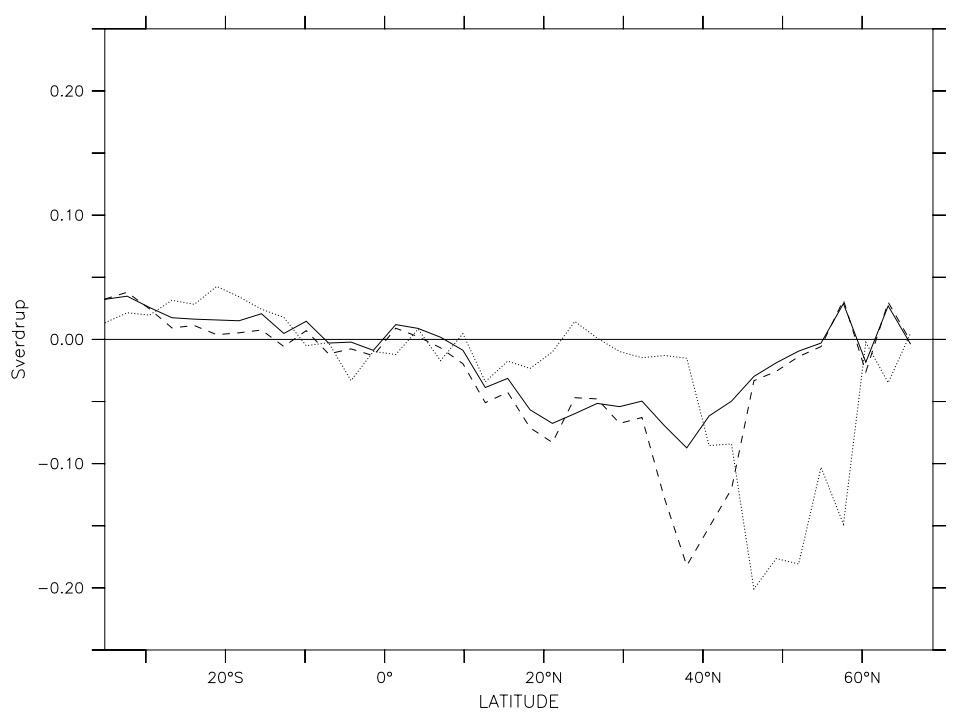

Fig. 9. Overturning component of the northward freshwater transport in the Atlantic Ocean for the control integration (solid line), and for the ocean states times at 201-250 yr (dotted line) and 801-850 yr (dashed lines) after the perturbation has been applied.

conveyor route would imply a saltier southward NADW outflow at $30^{\circ} \mathrm{S}$ than the northward upper branch. He concludes that the overturning freshwater forcing for the Atlantic Ocean is described as net freshening: surface water traveling through the Atlantic becomes diluted along the way (thermal driven circulation).

In order to reconcile this discrepancy, the overturning transport of freshwater, which is similar to the effective freshwater forcing of the Atlantic Ocean (Rahmstorf, 1996; Weijer et al., 1999), is interpreted. The analysis of our model experiments suggests that the THC is in the thermal branch for the North Atlantic (freshening due to weaker overturning), whereas in the South Atlantic it is in a haline-driven branch (salinity increases with weakened conveyor belt circulation). Therefore, the dispute whether the Atlantic flow regime is in the haline (e.g. Broecker et al., 1990) or thermal branch (e.g. Rahmstorf, 1996) may be shifted to the question of different regional responses in the Atlantic Ocean, i.e. a proper definition of the Atlantic boxes in a conceptual model framework.

\section{Concluding remarks}

The atmospheric hydrological cycle has a high mobility and links the THC with the Earth's water bud- get. Because little re-circulation of deep water occurs in the Atlantic, the atmospheric freshwater transport from the Atlantic basin makes the Atlantic saltier than the other oceans driving, at least partly, the global conveyor-belt circulation. The net Atlantic freshwater forcing has been recognized as an important external parameter of ocean sensitivity studies (e.g. Birchfield, 1989; Zaucker et al., 1994; Rahmstorf, 1996). Here, we find that the water vapor transport out of the Atlantic area is enhanced of $0.15 \mathrm{~Sv}$ for a state with weaker overturning circulation relative to the control experiment. This can be mainly attributed due an increased export at Central America and decreased import over Africa. The increased export at Central America is caused by increase in trade wind strength over the tropical Atlantic. The overturning component of the oceanic freshwater transport in the Atlantic Ocean shows a stabilizing effect of comparable magnitude to the atmospheric feedback, which is connected to an anomalous southward transport during the reversed overturning circulation.

The response of the climate to reduced overturning circulation, namely shifts of the ITCZ, temperature and salinity variations in the Atlantic, can be used to detect THC changes from paleoclimatic records. It it is interesting that the temperature response is strongest at high latitudes, whereas the hydrological response is strongest at the tropics. Increased water vapor export 
at the Isthmus of Panama is found to go in phase with net evaporation in the tropical North Atlantic: is opposite to the speculation of Peterson et al. (2000) that increased precipitation in this region is connected with a higher water vapor transport into the Pacific Ocean. This contradiction is, however, only related to the interpretation of the paleoclimatic record. The observed characteristic changes in the tropical hydrological cycle during Heinrich events and the Younger Dryas, related to the southward shift of the ITCZ, are consistent with a picture of a weaker Atlantic overturning circulation during those times.

This paper discusses the branch of the present-day conveyor belt circulation. From the numerical experiment shown here, it can be concluded that the salinity response due to reduced overturning is different for the southern and northern parts of the Atlantic Ocean. This cross-equatorial phenomenon is analogous to the seesaw effect (Crowley, 1992; Stocker, 1998) that a reduced Atlantic overturning circulation warms the atmosphere in the Southern Hemisphere. Interestingly, recent modeling work (Prange et al., 2002) suggests that the branch of the THC depends sensitively on the background climate: the present day circulation is in the thermal regime associated with bi-stability of the THC, whereas the glacial circulation is in the haline regime with one stable equilibrium only.

Finally, one can use the model response for a multivariable fingerprint in order to measure or reconstruct THC changes. Paleoclimatic proxies in the regions with a strong response to THC changes, low noise level and weak teleconnections with other climate phenomena could provide a basis for monitoring past, present and future climate shifts related to the ocean circulation.

\section{Acknowledgments}

M. Prange, S. Marsland, E. Maier-Reimer, U. Mikolajewicz, R. Voss and K. Arpe are gratefully acknowledged for their suggestions regarding the manuscript. The manuscript benefited furthermore from the comments of two anonymous referees. This work was partly supported by the BMBF through DEKLIM.

\section{REFERENCES}

Baumgartner, A. and Reichel, E. 1975. The world water balance. Elsevier, Amsterdam.

Bianchi, G. G. and McCave, I. N. 1999. Holocene periodicity in North Atlantic climate and deep-ocean flow south of Iceland. Nature 397, 515-517.

Birchfield, G. E. 1989. A coupled ocean-atmosphere climate model: temperature versus salinity effects on the thermohaline circulation. Climate Dyn. 4, 57-71.

Broecker, W. S. 1991. The great conveyor. Oceanography 4 , 79-89.

Broecker, W. S. 1992. The salinity contrast between the Atlantic and Pacific during glacial time. Paleoceanogr. 4, 207-212.

Broecker, W. S., Bond, G., Klas, M., Bonani, G. and Wolfi, W. 1990. A salt oscillator in the glacial Atlanic? 1. The concept. Paleoceanogr. 5, 469-477.

Bryan, F. 1986. High latitude salinity effects and inter hemispheric thermohaline circulations. Nature 323, 301-304.

Capelle, W. 1953. Die Vorsokratiker. Aristoteles, Metaphysics I 3.983b. Kröner, Stuttgart, 501 pp.

Clark, P. U., Marshall, S. J., Clarke, G. K. C., Horstetler, S. W., Licciardi, J. M. and Teller, J. T. 2001. Freshwater forcing of abrupt climate change during the last glaciation. Science 293, 283-286.

Dansgaard, W., Johnsen, S. J., Causen, H. B., Dahl-Jensen, D., Gundestrup, N. S., Hammer, C. U., Huidber, C. S., Steffensen, J. P., Sveinbjornsdottir, A. E., Jouzel, J. and Bond, G. 1993. Evidence for general instability of past climate from a 250-kyr ice-core record. Nature 364, 218220.

Drijfhout, S. S., Maier-Reimer, E. and Mikolajewicz, U. 1996. Tracing the conveyor belt in the Hamburg large-scale geostrophic ocean general circulation model. J. Geophys. Res. 101, 22 563-22 575.

Gordon, A. L. 1986. Interocean exchange of thermocline water. J. Geophys. Res. 91, 5037-5046.

Haug, G. H., Hughen, K. A., Sigman, D. M., Peterson, L. C. and Röhl, U. 2001. Southward migration of the intertropical convergence zone through the holocene. Science $\mathbf{2 9 3}$, 1304-1308.

Latif, M., Roeckner, E., Mikolajewicz, U. and Voss, R. 2000. Tropical stabilization of the thermohaline circulation in a greenhouse warming simulation. J. Climate 13, 18091813.

Lohmann, G. and Gerdes, R. 1998. Sea ice effects on the sensitivity of the thermohaline circulation in simplified atmosphere-ocean-sea ice models. J. Climate 11, 27892803.

Lohmann, G. and Lorenz, S. 2000. The water cycle under paleoclimatic conditions as derived from AGCM simulations. J. Geophys. Res. 105, 17417436.

Maier-Reimer, E., Mikolajewicz, U. and Hasselmann, K. 1993. Mean circulation of the Hamburg LSG OGCM and its sensitivity to thermohaline surface forcing. J. Phys. Oceanogr. 23, 731-757. 
Manabe, S. and Stouffer, R. J. 1988. Two stable equilibria of a coupled ocean-atmosphere model. J. Climate 1, 841-863.

Peixoto, J. P. and Oort, A. H. 1992. Physics of climate. American Institute of Physics. 520 pp.

Peterson, L. C., Haug, G. H., Hughen, K. A. and Röhl, U. 2000. Rapid changes in the hydrologic cycle of the tropical Atlantic during the last glacial. Science 290, 19471951.

Prange, M., Romanova, V. and Lohmann, G. 2002. The glacial thermohaline circulation: stable or unstable? Geophys. Res. Lett. 29, 2028, doi:10.1029/2002GL015337.

Prange, M., Lohmann, G. and Paul, A. 2003. Influence of vertical mixing on the thermohaline hysteresis: Analyses of an OGCM. J. Phys. Oceanogr. 33, 1707-1721.

Rahmstorf, S. 1995. Sensitivity of the North Atlantic circulation to changes in the hydrological cycle. Nature 378, $145-149$.

Rahmstorf, S. 1996. On the freshwater forcing and transport of the Atlantic thermohaline circulation. Climate Dyn. 12, 799-811.

Renssen H., Goosse, H., Fichefet, T. and Campin, J.-M. 2001. The 8.2 kyr BP event simulated by a global atmospheresea-ice-ocean model. Geophys. Res. Lett. 28, 15671570.

Rintoul, S. R. 1991. South Atlantic interbasin exchange. J. Geophys. Res. 96, 2675-2692.

Roeckner, E., Arpe, K., Bengtsson, L., Brinkop, S., Dümenil, L., Esch, M., Kirk, E., Lunkeit, F., Ponater, M., Rockel, B., Sausen, R., Schlese, U. Schubert, S. and Windelband, M. 1992. Simulation of the present-day climate with the ECHAM model: Impact of model physics and resolution. MPI Report 93, Hamburg, Germany.

Roemmich, D. H. and Wunsch, C. 1985. Two transatlantic sections: Meridional circulation and heat flux in the subtropical North Atlantic Ocean. Deep Sea Res. 32, 619-644.

Sausen, R., Barthels, R. K. and Hasselmann, K. 1988. Coupled ocean-atmosphere models with flux correction. Climate Dyn. 2, 154-163.

Sausen, R., Schubert, S. and Dümenil, L. 1994. A model of river runoff for use in coupled atmosphere-ocean models. J. Hydrol. 155, 337-352.
Sausen, R. and Voss, R. 1996. Techniques for asynchronous and periodically synchonous coupling of atmosphere and ocean models. Part I: General strategy and application to the cyclo-stationary case. Climate Dyn. 12, 595-604.

Schiller, A., Mikolajewicz, U. and Voss, R. 1997. The stability of the thermohaline circulation in a coupled oceanatmosphere general circulation model. Climate Dyn. 13, 325-347.

Schmittner A., Appenzeller, C. and Stocker, T. F. 2000. Enhanced Atlantic freshwater export during El Niño. Geophys. Res. Lett. 27, 1163-1166.

Soden, B. J. 2000. The sensitivity of the tropical hydrological cycle to ENSO. J. Climate 13, 538-549.

Starr, V. and Peixoto, J. 1958. On the global water vapor and the hydrology of deserts. Tellus 10, 189-194.

Stocker, T. F. 1998, The seesaw effect. Science 282, 61-62.

Tzipermann, E. 1997. Inherently unstable climate behaviour due to weak thermohaline circulation. Nature 386, 592595.

Voss, R. and Sausen, R. 1996. Techniques for asynchronous and periodically-synchonous coupling of atmosphere and ocean models. Part II: Impact on variability. Climate Dyn. 12, 605-614.

Voss, R., Sausen, R. and Cubasch, U. 1998. Periodically synchronously coupled integrations with the atmosphereocean general circulation model ECHAM3/LSG. Climate Dyn. 14, 249-266.

Weijer, W., de Ruiter, W.P.M., Dijkstra, H.A. and van Leeuwen, P.J. 1999. Impact of interbasin exchange on the Atlantic overturning circulation. J. Phys. Oceanogr. 29, 2266-2284.

Wijffels, S. E., Schmitt, R. W., Bryden, H. L. and Stigebrandt, A. 1992. Transport of fresh water by the oceans. J. Phys. Oceanogr. 22, 155-162.

Zaucker, F. and Broecker, W. S. 1992. The influence of atmospheric moisture transport on fresh water balance of the Atlantic drainage basin: General circulation model simulations and observations. J. Geophys. Res. 97, 2765-2773.

Zaucker, F., Stocker, T. F. and Broecker, W. S. 1994. Atmospheric freshwater fluxes and their effect on the global thermohaline circulation. J. Geophys. Res. 99, 12443-12457. 